\title{
Comfort of the patient's family in an Intensive Care Unit related to welcoming
}

\author{
CONFORTO DE FAMILIARES DE PESSOAS EM UNIDADE DE TERAPIA INTENSIVA \\ FRENTE AO ACOLHIMENTO
}

\section{CONFORT DE FAMILIARES DE PERSONAS EN UNIDAD DE CUIDADOS INTENSIVOS FRENTE A LA ACOGIDA}

\author{
Mariana de Almeida Moraes Gibaut ${ }^{1}$, Luisa Mayumi Rocha Hori², Kátia Santana Freitas ${ }^{3}$, \\ Fernanda Carneiro Mussi ${ }^{4}$
}

\begin{abstract}
This study aimed to identify the level of comfort of families of patients in a critical health condition related to the welcoming practices performed by the hospital staff. Interviews were conducted with 250 relatives in hospitals of the state Bahia, using a Likert scale. Data were analyzed as percentages and quartiles. For nine of the 12 statements of the scale, most relatives scored their comfort level between very and totally comfortable, median of 4 , revealing kindness, tranquility and friendly communication with family members. More than half of the sample scored its level as not at all to more or less comfortable, median of 3 , for statements about demonstration of interest towards the relative by the staff and flexible visiting of the patient. The necessity of greater interest of the team in the condition and needs of the family was observed. Promoting comfort from the dimension of welcoming demands interdisciplinary actions grounded in humanistic philosophy, in which the nurse has an important role to play.
\end{abstract}

\section{DESCRIPTORS}

Critical care

Family

User embracement

Family nursing

Professional-family relations

\section{RESUMO}

Objetivou-se identificar o nível de conforto de familiares de pessoas em estado crítico de saúde decorrente das práticas de acoIhimento da equipe hospitalar. Foram entrevistados 250 familiares em hospitais do Estado da Bahia, utilizando-se uma escala Likert. Os dados foram analisados em percentuais e separatrizes. Para nove das 12 afirmativas da escala, a maioria dos familiares pontuou seu nível de conforto entre muito e totalmente confortável, mediana de 4, revelando gentileza, tranquilidade e comunicação cordial com familiares. Mais da metade da amostra pontuou seu nível de nada a mais ou menos confortável, mediana $=3$, para afirmativas sobre demonstrações de interesse da equipe pelo familiar e flexibilização da visita ao ente. Constatou-se a necessidade de maior interesse da equipe quanto a condição e necessidade do familiar. A promoção do conforto na dimensão acolhimento demanda a interdisciplinaridade da ação assentada em filosofia humanística para o qual a enfermeira tem importante papel a desempenhar.

\section{DESCRITORES \\ Cuidados críticos \\ Família \\ Acolhimento \\ Enfermagem familiar \\ Relações profissional-família}

\section{RESUMEN}

El objetivo del estudio fue identificar el nivel de confort de familiares de personas en estado crítico de salud como resultado de las prácticas de acogida del equipo hospitalario. Se entrevistó a 250 familiares, en hospitales del Estado de Bahía y se utilizó la escala Likert. Los datos fueron analizados en porcentajes y separados en matrices. Para 9 (nueve) de las 12 (doce) afirmaciones de la escala, la mayoría de los familiares señaló su nivel de confort entre mucho y totalmente confortable; mediana de 4, revelando gentileza, tranquilidad y comunicación cordial con los familiares. Más de la mitad de la muestra señaló su nivel de nada a más o menos confortable (mediana=3), para las afirmaciones sobre las demostraciones de interés del equipo por el familiar y flexibilidad de la visita al paciente. Se constató la necesidad de mayor interés del equipo en relación a la condición y necesidad del familiar. Promover el confort en la acogida exige una acción interdisciplinaria basada en la filosofía humanística, donde la enfermera tiene un rol importante que desempeñar.

\author{
DESCRIPTORES \\ Cuidados críticos \\ Familia \\ Acogimiento \\ Enfermería de la familia \\ Relaciones profesional-familia
}

\footnotetext{
${ }^{1}$ Nurse. Master's student, Graduate Program, School of Nursing, Federal University of Bahia. Salvador, BA, Brazil. mary mlr@hotmail.com ${ }^{2}$ Nurse. Graduate of the School of Nursing, Federal University of Bahia. Salvador, BA, Brazil. luisa_hori@hotmail.com ${ }^{3}$ Nurse. Doctorate in Nursing. Professor, Health Department of the Feira de Santana State University. Feira de Santana, BA, Brazil. ksfenfpro@hotmail.com ${ }^{4}$ Nurse. Doctorate in Nursing. Associate Professor I, Department of Medical-Surgical Nursing and Nursing Administration, Federal University of Bahia School of Nursing. Salvador, BA, Brazil. femussi@ufba.br

$\begin{array}{cl}\text { Rev Esc Enferm USP } & \text { Received: 08/29/2011 } \\ \text { 2013; 47(5):1114-21 } & \text { Approved: 06/24/2013 }\end{array}$
}




\section{INTRODUCTION}

Comfort has been considered a fundamental concept related to nursing practice and a goal to be achieved through nurses' care, by national and international authors ${ }^{(1)}$.

Although the concern for comfort is historic, its conception has been conceived and raised predominantly from the referential of nurses, scientific rationale and hospital administration, not being taken into account the relationship of the individual with the disease and health practic$\mathrm{es}^{(1)}$. The phenomena is considered to be multidimensional; a positive and subjective experience, a state of wellbeing experienced in the physical, psychospiritual, sociocultural and environmental spheres ${ }^{(2-3)}$. It results from interactions that people establish with other beings, situations and objects and modifies itself through time and space ${ }^{(4)}$.

It is considered that the concept of comfort needs to be explored and understood based on the interactions of the patients with health services. Various studies have been developed in this perspective since the decade of the 1990 's ${ }^{(2-4)}$. However, little is known about the experience covering the comfort of relatives of patients in a critical health status.

The situation involving disease, service and hospitalization of a family member in general leads to a state of fragility, insecurity and fear related to the threat presented by the disease and the treatment. Facing these discomforts, the family needs to be comforted ${ }^{(5)}$.

When there is a hospitalization in an intensive care unit (ICU), both the patient and his relatives face a crisis because of the discomforts generated by the absence of family contact with the patient, the possibility of death, the change in life routine of a family, the lack of information about the health status of the patient, and the need to adjust to the routines imposed by the institution where the care is being provided.

Given this perspective, the family became the object of investigation and of nursing care ${ }^{(6)}$. The wide literature existing about family indicates the complexity of this subject, which has brought researchers from various disciplinary fields to agree with the fact that this subject requires a multi- or trans-disciplinary approach. Family needs to be seen as more than a residence unit in different points of time. It needs to be seen as a relational structure that involves its members, friends and neighbors. Thus, the concept of family must be used not only for people united by the bonds of blood, but also for those united by emotional bonds in a social context ${ }^{(7-8)}$.

The interaction of family within an institutional context may represent a source of discomfort. The entrance to an ICU to visit a very ill relative, with its noises and viewing wires, monitors, and people moving at every moment, impresses and generates fears, doubts and anxieties: it is for this reason that the family needs to be comforted. One way to meet this need consists of welcoming, which means to relate to one another in a meeting, using active listening and responsiveness, which requires reorganizing the work process in health and encompassing the different demands of the subject ${ }^{(9)}$. Finally, this reception can promote comfort ${ }^{(5,10)}$.

Qualitative research on the comfort experiences of the family of people in critical health status found that one of the dimensions of this construct lies precisely in the welcoming of the family ${ }^{(10)}$. The family felt more comfortable when considered as people with interpersonal relationships with the hospital care team. Comfort meant being respected, accepted, valued, heard and understood by the team, as well as the perception that the team was concerned with the family suffering and with possibilities to minimize it. For the family, comfort was promoted when they were treated kindly at the hospital front desk and in the ICU, treated with tranquility, greeted with a smile or approached with a conversation. The attitude of the staff as a way of showing interest in their needs, for example, knowing if they were prepared for the visit, accompanying them to the bed of the relative, providing an explanation of the cause of the visit delay, and ensuring the replacement of the lost time, meant comfort. Such actions may be included as indicators of welcoming for the promotion of comfort.

Welcoming in the context of health services is to receive well, listen the demands, seek ways to understand them and empathize with them. By welcoming, we enable the meeting, being present, the relationship, the creation of bonds among family, the hospitalized patient and the health team. This welcoming generates humanized relationships between caregivers and those who receive the care ${ }^{(10)}$. It does not consist of a space or place, but of an ethical posture, it does not require an hour or a specific professional to do it, it implies sharing knowledge, anguish and inventions, taking on the responsibility of to shelter and clothe others in their demands, with responsibility and resolution signaled by the case in question. This is an ongoing process, not just a stage of care, that is given at the entry to the health services, often related to open receptions for demand or triage. Given its value, it consists of one of the guidelines of major ethical relevance, esthetics and policy of the National Policy of Humanization of the Unified System of Health (SUS) ${ }^{(10)}$.

Due to the belief that the welcoming of the family in this scenario is fundamental for promotion of its comfort, the aim of the study was defined as: to identify the level of comfort of families of people in critical health 
status resulting from the welcoming practices of the hospital care team.

The study aims to contribute to the reflection and understanding of nurses and other health professionals regarding the situations of comfort and discomfort experienced by the family, as well as to evaluate the effectiveness of welcoming in promoting comfort. It can also strengthen the humanization policies of the Ministry of Health that identifies welcoming as a tool that must be used, due to the possibilities of expansion and effectiveness of humanized care, because it advocates the encounter, listening, bonding, and respect of the differences between health workers and users.

\section{METHOD}

This was a quantitative, cross-sectional study, conducted in six ICUs distributed in three public teaching hospitals of the State of Bahia. The research project, Construction and validation of the comfort scale for family of people in critical health status, from which this study was derived, was submitted for evaluation of the Ethics Committee for analysis of Research Projects, protocol CEP: 022/2009, and approved without restrictions.

Participants were relatives of patients admitted to ICU who met the inclusion criteria: being 18 years of age or older, have blood ties or being the closest person to the hospitalized patient that lived with him and maintained a close relationship, having an adult family member in the public health service ICU for more than 24 hours, having at least one visit to the relative, acceptance to participate in the study and signing of the Terms of Free and Informed Consent.

A convenience sample was used, that is, the study included those who agreed to participate and met the eligibility criteria. The sample size required was estimated at 246 participants, considering an alpha error of 0.05 and a beta of 0.20 .

Two instruments were used for data collection. The first was a demographic and clinical data form containing closed questions about the inpatient and the family. The second was a scale to measure the Level of Comfort of Family of ICU Patients, related to welcoming, which consisted of 12 statements based on previous qualitative research ${ }^{(11)}$. In this investigation comfort indicators (items, statements) were identified that supported the definition of seven dimensions of the comfort phenomenon, including the welcoming dimension.

In order to obtain a consistent instrument, content validity of the statements drawn from the previous qualitative research was conducted. This validity consisted of judging in which proportion the selected items measured a theoretical construction represent well all the important facets of the content to be measured.
This validity consisted of judging to what extent the items selected to measure a theoretical construct represented well all the important facets of the concept being measured. Such validity is a judgment process composed of the development of the instrument and its evaluation by specialists ${ }^{(12)}$ and it is an effective means of analyzing the judges and the semantic analysis.

These analyses aimed to verify correspondence among items and the dimension of welcoming, and welcoming with the construct of comfort of the family with patients in critical health status. For analysis by judges, seven professionals from different regions of the country and with experience in the area of the construct were invited, in order to judge whether the statements were or were not referring to the phenomenon in question and to comment individually about their relevance to the dimension of welcoming. Based on the considerations of the experts, the items were modified.

Furthermore, the 12 statements were subjected to semantic analysis along with the target population. Ten relatives were invited to participate individually, and five formed a focus group. They were oriented to listen and to signal any doubt as to the formulation and understanding of the statements. They considered all the sentences understandable.

The elaboration of instructions for the relative to rate his answer and the choice of the level of comfort scale scores preceded the semantic analysis, in order to identify potential problems. Since comfort is a subjective, dynamic state and the product of the interaction of family members with different social objects, a Likert-type attitude scale was used to measure the construct, with five categories of answers: 1 - not at comfortable, 2 - a little comfortable, 3 - more or less comfortable, 4 - very comfortable and 5 - totally comfortable. The scoring of the scales for the items increases, that is, the higher the value, the greater the comfort identified.

After analysis, 12 statements comprised the final instrument aimed at assessing the level of comfort of family members of patients with critical health status, resulting from the welcoming practices of the hospital care team (Chart 1).

Chart 1 - List of statements about the welcoming of family members - Salvador, 2011

\begin{tabular}{|ll|}
\hline \multicolumn{1}{|c|}{ Items } \\
\hline 1. & $\begin{array}{l}\text { Received a word of support from the team during } \\
\text { hospitalization in the ICU }\end{array}$ \\
\hline 2. & Noticed that the ICU team gave information willingly \\
\hline 3. & Felt that the ICU team was interested in knowing how you felt \\
\hline 4. & $\begin{array}{l}\text { Noticed that the professional did not insist that you leave as } \\
\text { soon as the visiting time ended }\end{array}$ \\
\hline
\end{tabular}

Continue...
Comfort of the patient's family in an Intensive Care Unit related to welcoming Gibaut MAM, Hori LMR, Freitas KS, Mussi FC 
...Continuation

Items

5. Were received with kindness in the ICU reception

6. Noticed that the team had patience to listen to the relatives

7. Noticed that the ICU professionals understood the situation you were experiencing

8. Noticed that you were served with tranquility by the team

9. Were allowed a larger number of visitors when necessary

10. Talked to someone from the team

11. Noticed that the team was interested in knowing if you were emotionally prepared for the visit

12. Were treated kindly by the professionals of the ICU

The technique of data collection, the interview, was accomplished in the period from July to November of 2010. Family members who met the inclusion criteria were approached by the interviewer in a private environment in the ICU. Prior to the meeting, an explanation of the reason for the approach and information about the study objectives were given, highlighting that participation in the study was voluntary, oriented on the completion of the Informed Consent, and the inclusion criteria were verified.

The data that was recorded and coded on the forms was entered into a database in the SPSS program, version 17.0 for Windows. It was analyzed in absolute numbers, percentages and quartiles. To estimate the overall score of the comfort level of the sample, a mean score of comfort of each family was obtained using the arithmetic mean of the 12 items answered; in other words, the individual scores for each statement were added and the sum was then divided by 12 . Thus, an average value was obtained for each participant and the overall score (continuous values) was estimated.

\section{RESULTS}

\section{Sociodemographic characteristics of the relatives and clinic of the hospitalized family member}

Of the 250 family members who were interviewed, the majority was female $(75.6 \%)$ with a mean age of 40.6 years $( \pm 11.9)$. Participants who were married or in a stable relationship (69.2\%), Catholics (59.2\%), followed by evangelics (30.8\%), with a high school degree (33.2\%) or middle school degree $(25.6 \%)$, economically active $(60 \%)$, and who had no previous experience of having family members in the ICU (66.4\%) were predominate. The majority was a child (44.8\%) or spouse (18.4\%) of the hospitalized patient, but only $44.8 \%$ lived with him. The interviewee was responsible for the family in $41.2 \%$ of the cases. They predominantly originated from different cities from those in which the study hospitals were located $(40 \%)$, followed by Salvador (39.6\%) and Feira de Santana (20.4\%).

As for the characterization of patients, the mean age was 55.8 years $( \pm 19.0)$ and the mean hospital stay was 8.2 days ( \pm 8.4$)$. The medical diagnosis was predominantly of a clinical nature $(50.8 \%)$, followed by surgical $(38.0 \%)$, and clinical with progression to surgical (11.2\%). Table 1 shows that for nine of the 12 statements, most family members scored their comfortable level between very and totally comfortable, and the median was 4 , which characterizes a very comfortable level. Yet, for all statements, up to $75 \%$ of the sample scored totally comfortable.

Table 1- Level of comfort of family members, according to statements related to the welcoming practices of the hospital care team - Salvador, 2011

\begin{tabular}{|c|c|c|c|c|c|c|c|c|c|c|c|}
\hline \multirow[b]{2}{*}{ STATEMENTS } & \multicolumn{2}{|c|}{$\mathrm{NC}$} & \multicolumn{2}{|c|}{ PC } & \multicolumn{2}{|c|}{ MMC } & \multicolumn{2}{|c|}{ MC } & \multicolumn{2}{|c|}{ TC } & \multirow{2}{*}{$\begin{array}{c}\text { Mi } \\
\begin{array}{c}\text { IQ } \\
{[p 25-p 75]}\end{array}\end{array}$} \\
\hline & $\mathbf{N}$ & $\%$ & $\mathbf{N}$ & $\%$ & $\mathbf{n}$ & $\%$ & $\mathbf{n}$ & $\%$ & $\mathbf{n}$ & $\%$ & \\
\hline $1(n=250)$ & 19 & 7,6 & 22 & 8,8 & 38 & 15,2 & 84 & 33,6 & 87 & 34,8 & $4[3-5]$ \\
\hline $2(\mathrm{n}=250)$ & 3 & 1,2 & 12 & 4,8 & 30 & 12 & 93 & 37,2 & 112 & 44,8 & $4[4-5]$ \\
\hline $3(n=250)$ & 81 & 32,4 & 34 & 13,6 & 50 & 20 & 41 & 16,4 & 44 & 17,6 & $3[1-4]$ \\
\hline $4\left(n=245^{*}\right)$ & 15 & 6 & 15 & 6 & 33 & 13,2 & 82 & 32,8 & 100 & 40,0 & $4[3-5]$ \\
\hline $5(n=250)$ & 3 & 1,2 & 11 & 4,4 & 26 & 10,4 & 100 & 40 & 110 & 44,0 & $4[4-5]$ \\
\hline $6(n=250)$ & 4 & 1,6 & 8 & 3,2 & 34 & 13,6 & 93 & 37,2 & 111 & 44,4 & $4[4-5]$ \\
\hline $7(n=250)$ & 14 & 5,6 & 24 & 9,6 & 40 & 16 & 88 & 35,2 & 84 & 33,6 & $4[3-5]$ \\
\hline $8(n=250)$ & 1 & 0,4 & 8 & 3,2 & 34 & 13,6 & 102 & 40,8 & 105 & 42 & $4[4-5]$ \\
\hline $9(\mathrm{n}=247 *)$ & 54 & 21,6 & 41 & 16,4 & 39 & 15,6 & 63 & 25,2 & 50 & 20 & 3 [2-4] \\
\hline $10(n=250)$ & 24 & 9,6 & 14 & 5,6 & 35 & 14 & 76 & 30,4 & 101 & 40,4 & $4[3-5]$ \\
\hline $11\left(\mathrm{n}=248^{*}\right)$ & 52 & 20,8 & 34 & 13,6 & 41 & 16,4 & 58 & 23,2 & 63 & 25,2 & $3[2-5]$ \\
\hline $12(n=250)$ & 2 & 0,8 & 6 & 2,4 & 31 & 12,4 & 93 & 37,2 & 118 & 47,2 & $4[4-5]$ \\
\hline
\end{tabular}

Legend: NC= Not at all comfortable; LC= A little comfortable; MLC= More or less comfortable; MC= Very comfortable; TC= Totally comfortable. Mi: Median IQR: Interquartile range

${ }^{*} \mathrm{~N}<250$ because the items were not scored by all families for the reason that the situation was not experienced by them. 
The following percentage was observed for the levels very and totally comfortable for the nine sentences: Were treated kindly by the professionals of the ICU (84.4\%), Were received with kindness in the ICU reception (84.0\%), Noticed that you were served with tranquility by the team (82.8\%), Noticed that the ICU team gave information willingly (82.0\%), Noticed that the team had patience to listen to the relatives (81.6\%), Noticed that the professional did not insist that you leave as soon as the visiting time ended (72.8\%), Talked to someone from the team (70.8\%), Noticed that the ICU professionals understood the situation you were experiencing $(68.6 \%)$ and Received a word of support from the team during hospitalization in the ICU (68.4\%).

It was verified that more than half of the sample scored the levels not at all to more or less comfortable for the statements Felt that the ICU team was interested in knowing how you felt (66.0\%), Were allowed a larger number of visitors when necessary (53.6\%) and Noticed that the team is interested in knowing if you were emotionally prepared for the visit (50.8\%). Such sentences obtained a median of 3 , that is, an average level of comfort.

It is emphasized that up to $25 \%$ of the sample obtained a low level of comfort for the statements Were allowed a larger number of visitors when necessary and Noticed that the team was interested in knowing if you were emotionally prepared for the visit (first quartile $=2$, that is, a little comfortable) and, Felt that the ICU team was interested in knowing how you felt (first quartile $=1$, that is, not at all comfortable) received a lower level.

The global score for level of comfort of the sample was: first quartile $=3.33$ (approximates the level 3, that is, more or less comfortable), Median $=3.83$ and third quartile $=4.33$ (approximate level 4, that is, very comfortable).

\section{DISCUSSION}

The family members participating in this study were characterized by being predominantly adults with a mean age of 40.6 years old, married or in a stable relationship, adherents of a religion, with varied education, with no previous experience of relatives hospitalized in ICU, and originating from different cities than those in which the study hospitals were located.

Women predominated among family members visiting the patient in the ICU. In a literature review about the health care within the family ${ }^{(13)}$, the authors noted that, in the analyzed studies, the majority of the interviewees were female. The figure of the woman as the primary caregiver appears almost like a consensus in the literature and the care provided by women is a worldwide phenomenon.

The sociocultural context emphasizes the woman as the caregiver for excellence and women define themselves as such, placing them in the position of responsibility for family care. It was seen, also, that the majority of relatives were children of ICU patients, followed by spouses, corroborating data from the literature, that wives and daughters are the most frequent caregivers ${ }^{(13)}$.

These family members faced a mean of 8.2 days of patient hospitalization, mobilizing to attend the hospitalization demands and to interact with a life-threatening situation of the patient, whose severity level was defined as predominantly serious, but stable, at the interview time.

The hospitalization of a family member in the ICU usually occurs unexpectedly, with little time for adjustment of the family. It is a stressful situation that makes people feel disorganized, helpless and facing difficulties to mobilize to meet the usual demands of daily life and also those arising from hospitalization ${ }^{(14)}$. It is worth noting that most family members were married women who, in our society in general, are typically responsible for the organization and care of family life.

In investigations about the perceptions of nurses regarding family members confronting the patient admission to the ICU ${ }^{(15-16)}$, the authors found demonstration of good knowledge about the crisis experienced by the family. The concerns related to the technical quality of the information, instead of how it was transmitted. For the family, the health professional was the one who controlled, in a sense, the life of their family member, and could provide explanations. Therefore, it is important that health professionals welcome the family ${ }^{(15)}$, with awareness and respect for their anxiety level, providing and repeating the information as necessary, offering to listen to the difficulties in order to facilitate their ability to confront this new and painful experience ${ }^{(17)}$.

The mean score of comfort level represented by the median and third quartile revealed a high level of comfort among family members interviewed, resulting from the welcoming practices of the hospital care team. "Noticed that the ICU team gave information willingly" was a source of much and total comfort for $82 \%$ of the family members.

The necessity of the majority of family members to obtain information/knowledge about what happens during hospitalization is presented in the literature ${ }^{(14)}$. To feel welcomed, family members need clarification on the rules and routines of the hospital ${ }^{(18)}$. Thus it is important that the health care team is available to meet the demands of information by the family. However, it should be noted that, for the family, simply receiving the information is not enough, the way in which it is transmitted must be accompanied by kindness and tranquility in gestures and words ${ }^{(15)}$.

The results seem to indicate that the ICU health teams established sensitive communication strategies to welcome the family in this time of sorrow. The results evidenced that kindness and tranquility permeated other actions performed by different types of professionals who worked in the ICU. This can be noticed through the statements Were received with kindness in the ICU reception, Noticed that you were
Comfort of the patient's family in an Intensive Care Unit related to welcoming Gibaut MAM, Hori LMR, Freitas KS, Mussi FC 
served with tranquility by the team and Were treated kindly by the professionals of the ICU. More than $80 \%$ scored very or totally comfortable, with a median of 4 and third quartile of 5. Such attitudes can express family acceptance by the people who work in the hospital unit ${ }^{(14)}$.

Noticed that the team had patience to listen to the relatives, Talked to someone on the team and Received a word of support from the team during hospitalization in the ICU consisted of professional practices that promoted comfort for most family members, because more than $68 \%$ scored them at the level of very or totally comfortable for these statements, with a median of 4 .

Welcoming seeks to listen, value the patient/family complaints, identify their needs and respect the differences, constituting a relational technology permeated through dialogue ${ }^{(19)}$. In time of crisis, to face the painful situation of hospitalization of a family member in the ICU, the family needs a hospital staff member who can assist them ${ }^{(19)}$. The simple fact that the professionals are open to listen to the family can decrease the anxiety felt by them.

The therapeutic encounter takes place in the dialogical dimension, that is, the opening of a genuine interest in listening to the person to whom we devote our best practices, and to be heard by him. It is in the continuous interaction between users and the health service in all opportunities that the possibility of listening to each other is presented, that is the welcoming, which should have this ability of listening among its qualities ${ }^{(20)}$. And it is not quality in the sense of good or bad, but from the nature of this listening, of what one wants to hear.

The statement, Noticed that the ICU professionals understood the situation you were experiencing was considered by more than $65 \%$ of the sample to be between very and totally comfortable. In contrast, two other statements that also demanded the establishment of a connection between the family and staff, and expressing emotional involvement between them, resulted in lower levels of comfort: Felt that the ICU team was interested in knowing how you felt $(46 \%$ of the family members indicated not at all or a little comfortable, $\mathrm{Mi}=3$ ) and Noticed that the team was interested in knowing if you were emotionally prepared for the visit (34.4\% between not at all or a little comfortable, $\mathrm{Mi}=3$ ).

This reveals that the interactions of professionals cannot be guided only by the cordiality and superficial approach of the family, let alone to settle on merely normative actions, without worrying about the real feelings of those who should be the target of their practice.

It is valid to consider that defense mechanisms to suffering are developed by health professionals, and this may be one explanation for the superficiality of their involvement with family members. The fragmentation of the nurse-patient relationship, depersonalization and denial of the importance of the individual and the rationalization of feelings are some of the defense mechanisms used by professionals ${ }^{(1)}$. However, family comfort arises from interaction and emotional demonstrations of the health team.

The ICU visits are important to ensure the minimum proximity between the patient and family, as their life together was interrupted by the hospitalization. However, it is not enough to only allow the entry of the family into the ICU, it is necessary to prepare them and accompany them during the visit, identifying and clarifying their doubts, observing the reactions and behaviors and especially understanding their feelings. Professionals need to recognize that, at this moment, the family is also anxious, afraid of death, of being confronted with the condition of their relative and the ICU environment, experiencing human suffering, often without having control of the situation and not knowing how to behave during the visit.

Considering that the practice of welcoming has its foundation in interpersonal relationships and humanized care, the need to technically and emotionally prepare health professionals for welcoming in the ICU is perceived, in order to equip and motivate them to provide sensitive care to the needs of users.

Also regarding the visit in the ICU, the role of the nurse deserves importance, as the visit process is usually coordinated by her, emphasizing that the rules and hospital routines need to be flexible due to the needs and justification of the family members, which includes thinking and facilitating their stay as long and whenever possible.

In a study on the care of nurses for families ${ }^{(17)}$, the flexible visit was the intervention most often practiced, confirming it as a way to promote comfort as described in other studies ${ }^{(11)}$. It was noted that $72.8 \%$ of the sample considered themselves to be very or totally comfortable when realizing that the professionals did not insist on their leaving immediately at the end of the visit.

In contrast, $38 \%$ of family members scored their comfort level between not at all and a little comfortable on the statement: Were allowed a larger number of visitors when necessary. Professional actions guided strictly by hospital standards were classified as non-humanized ${ }^{(21)}$ and a rigid schedule for family stay at the hospital, with limited space and lack of professional availability for the family, were some of the barriers encountered in the interaction with the staff, which demonstrated a deficiency in welcoming practices ${ }^{(22)}$.

Although some studies ${ }^{(14,17)}$ pointed to an improvement with respect to the focus of attention not only on patients but also on their families, it was seen that progress such as the increased length of visit and others are still not sufficient to promote the comfort of the family members. Other factors still require improvement, these factors are essential to the family members feeling welcomed by the institution and professional staff that will surround them during the hospitalization of the patient. 
A study that aimed to understand the meaning of the ICU stay for relatives of patients ${ }^{(21)}$ showed that little consideration and care still existed for the family members by the health professionals, often caused by the difficulty of articulating sensitivity with rationality, due to their educational preparation.

In this study, although most family members felt very or totally comfortable with most statements related to the welcoming practices of the professionals, it is important to note that in all statements there were family members who reported being not at all comfortable, allowing for the realization of the existence of gaps that need to be filled, and that the challenge of investing in promoting comfort should be constant and daily.

The nursing staff plays a key role in welcoming, considering their 24 hour presence in the hospital, and therefore the greatest opportunity to approach the family to identify its needs. In addition, it is the nurse that manages the visit in the ICU and is empowered to be flexible with the norms and hospital routines. Thus, nursing professionals should be qualified to welcome the family and contribute to promotion of its comfort. Additionally, hospitals need to ensure a sufficient number of nursing professionals, allowing the dignified exercise of the profession.

\section{REFERENCES}

1. Mussi FC. Conforto e lógica hospitalar: análise a partir da evolução histórica do conceito conforto na enfermagem. Acta Paul Enferm. 2005;18(1):72-81.

2. Kolcaba K. Comfort theory and practice: a vision for holistic health care and research. New York: Springer; 2003.

3. Tutton E, Seers K. An exploration of the concept of comfort. J Clin Nurs. 2003;12(5):689-96.

4. Mussi FC, Koizumi MS, Angelo M, Lima MS. Perda da espontaneidade da ação: o desconforto de homens que sofreram infarto agudo do miocárdio. Rev Esc Enferm USP. 2002;36(2):115-24.

5. Lourenço EC, Neves EP. As necessidades de cuidado e conforto de visitantes em UTI oncológica: uma proposta fundamentada em dados de pesquisa. Rev Bras Cancerol. 2008;54(3):213-20.

6. Ângelo $M$, Bousso RS, Rossato $L M$, Damião EBC, Silveira $A O$, Castilho AMC, et al. Family as an analysis category and research field in nursing. Rev Esc Enferm USP [Internet]. 2009 [cited 2011 July 21];43(n.spe2):1337-41. Available from: http://www.scielo.br/pdf/reeusp/v43nspe2/en_a33v43s2. pdf

7. Casanova EG, Lopes GT. Comunicação da equipe de enfermagem com a família do paciente. Rev Bras Enferm. 2009;62(6):831-6.
Promoting comfort through welcoming practices should be understood as the right of a family that has a relative in the ICU, according to the National Policies of Humanization of SUS, which addresses the family as the subject of welcoming actions, involved in the therapeutic project.

\section{CONCLUSION}

The study showed the sensitivity of the professionals in interactions with family members, considering the level of variation of comfort from very to totally in most of the statements that expressed welcoming practices of the hospital care team. However, in three statements, more than half of the sample scored its comfort level between not at all and more or less comfortable, highlighting the need for demonstration of interest of the team about the family condition in this context, and the flexibility of norms and hospital routines to ensure welcoming.

The study points to the importance of technical skills and emotional preparation of professionals working in the ICU, with a view toward welcoming. The promotion of comfort in this dimension demands interdisciplinary actions, and an integrated teamwork based on a humanistic philosophy in which the nurse has an important role to play.

8. Rangel ML. Desafios e limites de estratégias de promoção da saúde dirigidas à família. Rio de Janeiro: FIOCRUZ; 2010. Família contemporânea e saúde; p.157-75.

9. Pinho LB, Santos SMA. Dialética do cuidado humanizado na UTI: contradições entre o discurso e a prática profissional do enfermeiro. Rev Esc Enferm USP. 2008; 42(1):66-72.

10. Brasil. Ministério da Saúde; Secretaria de Atenção à Saúde, Núcleo Técnico da Política Nacional de Humanização. Acolhimento nas práticas de produção de saúde. Brasília; 2006.

11. Freitas KS, Menezes IG, Mussi FC. Conforto na perspectiva de familiares de pessoas internadas em Unidades de Terapia Intensiva. Texto Contexto Enferm. 2012;21(4):896-904.

12. Alexandre NMC, Coluci MZO. Validade de conteúdo nos processos de construção e adaptação de instrumentos de medidas. Ciênc Saúde Coletiva. 2011;16(7):3061-8.

13. Gutierrez DMD, Minayo MCS. Produção de conhecimento sobre cuidados da saúde no âmbito da família. Ciênc Saúde Coletiva. 2010;15 Supl. 1:1497-508.

14. Freitas KS, Kimura M, Ferreira KASL. Necessidades de familiares de pacientes em Unidades de Terapia Intensiva: análise comparativa entre hospital público e privado. Rev Latino Am Enferm. 2007;15(1):84-92. 
15. McKiernan M, McCarthy G. Family members' lived experience in the intensive care unit: a phemenological study. Intensive Crit Care Nurs. 2010;26(5):254-61.

16. Maxwell KE, Stuenkel D, Saylor C. Needs of family members of critically ill patients: a comparison of nurse and family perceptions. Heart Lung. 2007;36(5):367-76.

17. Buckley P, Andrews T. Intensive care nurses' knowledge of critical care family needs. Intensive Crit Care Nurs. 2011;27(5):263-72.

18. Prochnow AG, Santos JLG, Pradebon VM, Schimith MD. Acolhimento no âmbito hospitalar: perspectivas dos acompanhantes de pacientes hospitalizados. Rev Gaúcha Enferm. 2009;30(1):11-8.
19. Schneider DG, Manschein AMM, Ausen MAB, Martins JJ, Albuquerque GL. Acolhimento ao paciente e família na unidade coronariana. Texto Contexto Enferm. 2008;17(1):81-9.

20. Ayres JRCM. O cuidado, os modos de ser (do) humano e as práticas de saúde. Saúde Soc. 2004;13(3):16-29.

21. Faquinello $\mathrm{P}$, Higarashi IH, Marcon SS. $\mathrm{O}$ atendimento humanizado em unidade pediátrica: percepção do acompanhante da criança hospitalizada. Texto Contexto Enferm. 2007;16(4):609-16.

22. Bettinelli LA, Rosa J, Erdmann AL. Internação em Unidade de Terapia Intensiva: experiência de familiares. Rev Gaúcha Enferm. 2007;28(3):377-84. 